\title{
Computation of Temperature Conductivity of Frozen Wood during its Defrosting
}

\section{Računanje toplinske vodljivosti smrznutog drva tijekom postupka odmrzavanja}

\author{
Original scientific paper • Izvorni znanstveni rad \\ Received-prispjelo: 18. 9. 2013. \\ Accepted-prihvaćeno: 20. 5. 2015. \\ UDK: $630 * 812.14 ; 630 * 812.25 ; 674.032 .13 ; 674.031 .632 .26 ; 674.031 .632 .22 ; 674.031 .739 .12 ; 674.031 .628 .224$ \\ doi:10.5552/drind.2015.1351
}

\begin{abstract}
An approach for the computation of the temperature conductivity of frozen wood during its defrosting has been suggested. The approach takes into account the physics of the processes of melting of both the frozen bound and free water in the wood in respective temperature ranges. It reflects for the first time also the influence of the fiber saturation point and of the volume shrinkage of each wood species on its temperature conductivity coefficient in frozen state.

In the present paper, the suggested approach for the computation of the temperature conductivity of poplar, spruce, beech, oak, walnut and acacia in the temperature range between $-60^{\circ} \mathrm{C}$ and $-1{ }^{\circ} \mathrm{C}$ is used. It is determined that the temperature conductivity of wood, during melting of frozen bound water in it, is up to some tens of times larger than the temperature conductivity of wood during melting of frozen free water in it.

The obtained results can be used both for technological and other engineering calculations and analysis of processes of thermal and hydrothermal treatment of wood materials, as well as in software of systems for model based automatic control of such treatment.
\end{abstract}

Key words: temperature conductivity, frozen wood, frozen bound water, frozen free water, computation

SAŽETAK • U radu se daje preporuka za izračunavanje toplinske vodljivosti smrznutog drva tijekom procesa odmrzavanja. U pristupu se uzima u obzir fizika procesa topljenja smrznute vezane i slobodne vode u drvu u odgovarajućim temperaturnim rasponima. Predloženim se pristupom po prvi put uzima u obzir utjecaj točke zasićenosti vlakanaca $i$ volumnog utezanja svake vrste drva na njezin koeficijent vodljivosti topline u smrznutom stanju.

U radu se predlaže pristup za izračunavanje toplinske vodljivosti drva topole, smreke, bukve, hrasta, oraha $i$ bagrema u temperaturnom rasponu između $-60{ }^{\circ} \mathrm{C} i-1{ }^{\circ} \mathrm{C}$. Utvrđeno je da je toplinska vodljivost drva tijekom topljenja smrznute vezane vode u drvu do nekoliko desetaka puta veća od toplinske vodljivosti drva tijekom topljenja smrznute slobodne vode u njemu.

Dobiveni se rezultati mogu upotrijebiti za tehnološke i druge inženjerske proračune $i$ analize procesa toplinske $i$ hidrotermičke obrade drvnog materijala, kao i pri izradi softvera za sustave automatskog upravljanja tim procesima.

Ključne riječi: toplinska vodljivost, smrznuto drvo, smrznuta vezana voda, smrznuta slobodna voda, proračun

\footnotetext{
${ }^{1}$ Authors are professor, PhD student and assistant professors at Faculty of Forest Industry, University of Forestry, Sofia, Bulgaria. ${ }^{2}$ Author is professor at Faculty of Wood Science and Technology, Technical University in Zvolen, Zvolen, Slovakia.

${ }^{1}$ Autori su profesor, doktorantica i docenti na Fakultetu za Industriju u šumarstvu, Šumarskog Sveučilišta u Sofiji, Bugarska. ${ }^{2}$ Autor je profesor na fakultetu za Znanost i tehnologiju drva, Tehničkog Sveučilišta u Zvolenu, Slovačka.
} 


\section{INTRODUCTION}

\section{UVOD}

For the technological and other engineering calculations of processes of thermal and hydrothermal treatment of wood materials, the wood temperature conductivity coefficient $a$ is often used. It is known that it represents the relationship of the thermal conductivity coefficient $\lambda$ to the multiplication of the specific heat capacity $c$ and density $\rho$ of the material. During calculations of heating or cooling of non-frozen wood, its temperature conductivity coefficient can be determined according to that relationship using the values of $c, \lambda$, and $\rho$ of the wood for specific temperature and moisture content.

During the calculation of the freezing or defrosting processes of wood, however, it is necessary to take into account the impact both of the specific heat capacity of the wood itself, and of the heat of the phase transition of water in the wood from its liquid to hard aggregate condition and vise versa upon the wood temperature conductivity coefficient.

The heat of the water phase transition in the wood can be represented by the specific heat capacity of the frozen hygroscopically bound $\left(c_{\mathrm{bw}}\right)$ and the frozen free $\left(c_{\mathrm{fw}}\right)$ water in the wood. As a result of in-depth dissertation studies, Chudinov (1966) discovers that the melting of the frozen free water in the wood takes place at temperatures in the range between $-2{ }^{\circ} \mathrm{C}$ and $-1{ }^{\circ} \mathrm{C}$. The author also discovers that the melting of the frozen hygroscopically bound water in the wood ends at $-2{ }^{\circ} \mathrm{C}$, and besides this, the quantity of this frozen water increases with the decrease in temperature, but even during extremely small climatic temperatures on earth, a definite part of it, $u_{\mathrm{nfw}}$, remains in a non-frozen state.

Subsequently for the determination of $a$ during the calculation of the wood defrosting processes, it makes sense to use the so called effective specific wood capacity $c$, which in the range $-2{ }^{\circ} \mathrm{C}<t \leq-1{ }^{\circ} \mathrm{C}$ is equal to the sum of $c$ and $\left(c_{\mathrm{fw}}\right)$, and when $t \leq-2{ }^{\circ} \mathrm{C}$ and simultaneously $u_{\mathrm{nfw}}<u \leq u_{\mathrm{fsp}}$, then $c_{\mathrm{e}}=c+c_{\mathrm{bw}}$ (Chudinov, 1966; Deliiski, 2003b).

For a precise determination of the wood temperature conductivity coefficient, it is also necessary to take into account the impact of the fiber saturation point of the wood $u_{\text {fsp }}$, which for the various wood species changes in a large range between $0.2 \mathrm{~kg} \cdot \mathrm{kg}^{-1}$ and 0.4 $\mathrm{kg} \cdot \mathrm{kg}^{-1}$ (Perelygin, 1965; Nikolov and Videlov, 1987; Chudinov, 1966, 1968; Reginač et al., 1990; Shubin, 1990; Požgaj et al., 1997; Trebula and Klement, 2002; Pervan, 2009; Kurjatko et al., 2010; Videlov, 2003; Deliiski, 2003b; Dzurenda and Deliiski, 2010).

The aim of the present work is to suggest an approach for the computation of the temperature conductivity of the wood during defrosting of the ice, which is created by both the hygroscopically bound and free water in the wood, using the mathematical descriptions of thermo-physical characteristics of frozen wood, made earlier by one of the authors.

\section{MATHERIAL AND METHODS}

\section{MATERIJAL I METODE}

2.1 Computation of $a$ at temperatures $T \leq \mathbf{2 7 1 . 1 5}$ $\mathrm{K}$ and wood moisture content $u \geq 0 \mathrm{~kg} \cdot \mathrm{kg}^{-1}$

2.1. Izračun koeficijenta toplinske vodljivosti pri temperaturi $T \leq 271.15 \mathrm{~K}$ i sadržaju vode $u \geq 0 \mathrm{~kg} \cdot \mathrm{kg}^{-1}$

As described in the introduction, during the calculations of the wood defrosting processes at $T \leq$ $271.15 \mathrm{~K}$ (i.e. at $t \leq-2{ }^{\circ} \mathrm{C}$ ) and $u_{\mathrm{fsp}} \geq u>u_{\mathrm{nfw}}$, the wood temperature conductivity must be determined according to the following equation (Deliiski, 2003b):

$a\left(T, u, u_{\mathrm{fsp}}\right)=\frac{\lambda\left(T, u, u_{\mathrm{fsp}}\right)}{\left[c\left(T, u, u_{\mathrm{fsp}}\right)+c_{\mathrm{bw}}\left(T, u, u_{\mathrm{fsp}}\right)\right] \cdot \rho\left(\rho_{\mathrm{b}}, T, u, u_{\mathrm{fsp}}, S_{\mathrm{v}}\right)}(1)$

where $a$ is temperature conductivity of the wood with frozen bound water in it $\left(\mathrm{m}^{2} \cdot \mathrm{s}^{-1}\right), \lambda$ is thermal conductivity of the wood $\left(\mathrm{W} \cdot \mathrm{m}^{-1} \cdot \mathrm{K}^{-1}\right), c$ is specific heat capacity of the wood itself $\left(\mathrm{J} \cdot \mathrm{kg}^{-1} \cdot \mathrm{K}^{-1}\right), c_{\mathrm{bw}}$ is specific heat capacity of the frozen bound water in the wood, $\left(\mathrm{J} \cdot \mathrm{kg}^{-1} \cdot \mathrm{K}^{-1}\right), \rho$ is wood density $\left(\mathrm{kg} \cdot \mathrm{m}^{-3}\right), \rho_{\mathrm{b}}$ is basic wood density equal to dry mass divided to green volume $\left(\mathrm{kg} \cdot \mathrm{m}^{-3}\right), S_{\mathrm{v}}$ is volume shrinkage of the wood (\%), $u$ is wood moisture content $\left(\mathrm{kg} \cdot \mathrm{kg}^{-1}\right), u_{\mathrm{fsp}}$ is wood moisture content at fibre saturation point $\left(\mathrm{kg} \cdot \mathrm{kg}^{-1}\right), T$ is temperature $(\mathrm{K})$.

The thermal conductivity $\lambda$ and the own specific heat capacity $c$ of the frozen wood during its defrosting is described mathematically using the data experimentally determined in the dissertations of Kanter (1955) and Chudinov (1966) for its change as a function of $t$ and $u$. The same experimental data for $\lambda$ and $c$, obtained by Kanter and Chudinov, are widely used in both the European literature (Sergovski, 1975; Shubin, 1990; Trebula, 1996; Trebula and Klement, 2002; Videlov, 2003) and the American specialized literature (Steinhagen, 1986, 1991; Khatabbi and Shteinhagen, 1992, 1993, 1995), when calculating various processes of thermal treatment of wood.

In the description of $a$ apart from $t$ and $u$, the independent parameter $u_{\mathrm{fsp}}$ has been input, which is different for the separate wood species and reflects the influence of the anatomic characteristics of the wood on $\lambda$ and $c_{\mathrm{e}}$ (Deliiski 2003b; Deliiski and Dzurenda, 2010). The mathematical description of the wood density $\rho$, depending on the moisture content $u, u_{\text {fsp }}$, the basic density, $\rho_{\mathrm{b}}$, and (only in the hygroscopic range) the volume shrinkage, $S_{v}$, which influence it, has been carried out using the experimental values set by (Sergovski, 1975) and shown in (Deliiski, 1977, 2003b, 2011).

The wood thermal conductivity $\lambda$ in equation (1) can be calculated with the help of the equations (Deliiski, 1994, 2003b, 2013c):

$$
\lambda=\lambda_{0} \cdot \gamma \cdot[1+\beta \cdot(T-273.15)]
$$

where

$$
\begin{aligned}
\lambda_{0}= & \mathrm{K}_{\mathrm{ad}} \cdot v \cdot[0.165+(1.39+3.8 \cdot \mathrm{u}) . \\
& \left.\cdot\left(3.3 \cdot 10^{-7} \cdot \rho_{\mathrm{b}}^{2}+1.015 \cdot 10^{-3} \cdot \rho_{\mathrm{b}}\right)\right]
\end{aligned}
$$




$$
\begin{gathered}
v=0.15-0.07 \cdot u @ u \leq u_{\mathrm{fsp}}+0.1 \mathrm{~kg} \cdot \mathrm{kg}^{-1} \\
v=0.1284-0.013 \cdot u @ u>u_{\mathrm{fsp}}+0.1 \mathrm{~kg} \cdot \mathrm{kg}^{-1}
\end{gathered}
$$

The equations, which have been suggested by Chudinov $(1966,1968)$ and shown in (Deliiski, 1977) can be used for the determination of the values of the coefficient $K_{\text {ad }}$ in equation (3), which takes into account the influence on $\lambda_{0}$ of the heat flux towards the separate anatomic directions of the wood. Deliiski (2003b) determined more precise values of $K_{\text {ad }}$ for ten wood species. For wood species discussed below in this paper, the following values of $K_{\text {ad }}$ cross sectional to the fibers (i.e. of $K_{\mathrm{ad}}=K_{\mathrm{c}}$ ) have been determined: $K_{\mathrm{c}}=$ 1.13 for oak, $K_{\mathrm{c}}=1.15$ for acacia, $K_{\mathrm{c}}=1.24$ for walnut, $K_{\mathrm{c}}=1.28$ for beech, $K_{\mathrm{c}}=1.33$ for spruce, $K_{\mathrm{c}}=1.42$ for poplar wood.

The coefficients $\gamma$ and $\beta$ in equation (2) are calculated by the following equations:

- For non-frozen wood, i.e. when $T_{\mathrm{dfr}}<T \leq 423.15 \mathrm{~K}$ and simultaneously with this $u>u_{\text {nfw }}$ or when $u \leq$ $u_{\text {nfw }}$ and simultaneously with this $213.15 \mathrm{~K} \leq T \leq$ $423.15 \mathrm{~K}$ :

$$
\begin{gathered}
\gamma=1.0 \\
\beta=(2.05+4 \cdot u) \cdot\left(\frac{579}{\rho_{\mathrm{y}}}-0.124\right) \cdot 10^{-3} \\
@ u \leq u_{\mathrm{fsp}}+0.1 \mathrm{~kg} \cdot \mathrm{kg}^{-1} \\
\beta=3.65 \cdot\left(\frac{579}{\rho_{\mathrm{y}}}-0.124\right) \cdot 10^{-3} \\
@ u>u_{\mathrm{fsp}}+0.1 \mathrm{~kg} \cdot \mathrm{kg}^{-1} \\
u_{\mathrm{fsp}}=u_{\mathrm{fsp}}^{293.15}-0.001 \cdot(T-293.15)
\end{gathered}
$$

- For frozen wood, i.e. when $213.15 \mathrm{~K} \leq T \leq T_{\mathrm{dfr}}$ and simultaneously with this $u>u_{\mathrm{nfw}}$ :

$$
\begin{gathered}
\gamma=1+0.34 \cdot\left[1.15 \cdot\left(u-u_{\mathrm{fsp}}\right)\right] \\
\beta=0.002 \cdot\left(u-u_{\mathrm{fsp}}\right)-0.0038 \cdot\left(\frac{579}{\rho_{\mathrm{b}}}-0.124\right)
\end{gathered}
$$

$$
\begin{gathered}
u_{\mathrm{nfw}}=0.12+\left(u_{\mathrm{fsp}}-0.12\right) \exp [0.0567 \cdot(T-271.15)] \\
@ 213.15 \mathrm{~K} \leq T \leq 271.15 \mathrm{~K} \\
T_{\mathrm{dfr}}=271.15+\frac{\ln \frac{u_{\mathrm{nfw}}-0.12}{u_{\mathrm{fsp}}-0.12}}{0.0567} \\
@ 0.12 \mathrm{~kg} \cdot \mathrm{kg}^{-1} \leq u=u_{\mathrm{nfw}} \leq u_{\mathrm{fsp}}^{271.15} \\
T_{\mathrm{dfr}}=271.15 @ u>u_{\mathrm{fsp}}^{271.15} \\
u_{\mathrm{fsp}}=u_{\mathrm{fsp}}^{293.15}-0.001 \cdot\left(T_{\mathrm{dfr}}-293.15\right) @ T \leq T_{\mathrm{dfr}}
\end{gathered}
$$

In equations (12) and (13) $u_{\mathrm{nfw}}$ is the amount of the non-frozen bound water in the wood (in $\mathrm{kg} \cdot \mathrm{kg}^{-1}$ ) at given temperature $T \leq 271.15 \mathrm{~K}$ and in equations (13), (14), and (15) $T_{\mathrm{drr}}$ is the temperature (in K), at which the melting of the frozen bound water in wood with given $u$ is completed. In equations (9) and (15) $u_{\mathrm{fsp}}^{293.15}$ is the fiber saturation point of the wood at $T=293.15 \mathrm{~K}$, i.e. at $t=$ $20{ }^{\circ} \mathrm{C}$, and in equations (13) and (14) $u_{\mathrm{fsp}}^{271.15}$ is the fiber saturation point of the wood at $T=271.15 \mathrm{~K} \mathrm{~K}$, i.e. at $t$ $=-2{ }^{\circ} \mathrm{C}$ (Stamm, 1964; Deliiski 2013b, 2013c).

The values for basic wood density $\rho_{\mathrm{b}}$ and for moisture content at fibre saturation point at $T=293.15$ $\mathrm{K}$ of wood species discussed below in this paper are shown in Table 1.

The specific heat capacity of the frozen wood itself $c$ in equation (1) can be calculated with the help of the following equations (Deliiski 1990, 2011; Deliiski and Dzurenda, 2010):

$$
\begin{array}{r}
c=K_{\mathrm{c}} \cdot \frac{526+2.95 \cdot T+0.0022 \cdot T^{2}+2261 \cdot \mathrm{u}+1976 \cdot u_{\mathrm{nfw}}}{1+u} \\
K_{\mathrm{c}}=1.06+0.04 \cdot u+\frac{0,00075 \cdot(T-271.15)}{u_{\mathrm{nfw}}}
\end{array}
$$

where $u_{\text {nfw }}$ is determined according to equation (12).

For the calculation of the specific heat capacity of the frozen bound water in the wood, $c_{\mathrm{bw}}$, the following equation (Deliiski, 2003b, 2004, 2011) has been obtained:

$$
\begin{aligned}
c_{\mathrm{bw}}= & 1.8938 \cdot 10^{4} \cdot\left(u_{\mathrm{fsp}}-0.12\right) \frac{\exp [0.0567 \cdot(T-271.15)]}{1+u} \\
& \text { @ } u_{\mathrm{fsp}} \geq u>u_{\mathrm{nfw}}
\end{aligned}
$$

Table 1 Basic density, wood moisture content at fibre saturation point at $20^{\circ} \mathrm{C}$, and volume shrinkage of some wood species (acc. to Perelygin, 1965; Nikolov and Videlov, 1987; Reginač et al., 1990; Požgaj et al., 1997; Kurjatko et al., 2010) Tablica 1. Osnovna gustoća, sadržaj vode pri zasićenosti vlakanaca pri $20{ }^{\circ} \mathrm{C}$ te volumno utezanje nekih vrsta drva (prema Perelygin, 1965.; Nikolov and Videlov, 1987.; Reginač et al., 1990.; Požgaj et al., 1997.; Kurjatko et al., 2010.)

\begin{tabular}{|c|l|c|l|c|}
\hline $\begin{array}{c}\text { № } \\
\text { Red. } \text { br. }\end{array}$ & \multicolumn{1}{|c|}{$\begin{array}{c}\text { Wood species } \\
\text { Vrsta drva }\end{array}$} & $\begin{array}{c}\text { Basic density } \rho_{\mathbf{b}} \\
\text { Gustoća drva } \\
\mathrm{kg} \cdot \mathrm{m}^{-3}\end{array}$ & $\begin{array}{c}\text { Fiber saturation point } u_{\mathrm{fsp}}^{293.15} \\
\text { Točka zasićenosti vlakanaca } \\
\mathrm{kg} \cdot \mathrm{kg}^{-1}\end{array}$ & $\begin{array}{c}\text { Volume shrinkage } \\
\text { Volumnmo utezanje } \\
S_{\mathrm{v}}, \%\end{array}$ \\
\hline 1. & Poplar / topola & 355 & 0.35 & 13.3 \\
\hline 2. & Spruce / smreka & 380 & $0.26-$ core; $0.32-$ sapwood & 11.4 \\
\hline 3. & Walnut / orah & 555 & $0.24-$ core & 12.9 \\
\hline 4. & Beech / bukva & 560 & 0.31 & 17.3 \\
\hline 5. & Acacia / bagrem & 660 & $0.20-$ core; $0.30-$ sapwood & 11.2 \\
\hline 6. & Oak / hrast & 670 & 0.22 - core; $0.29-$ sapwood & 11.9 \\
\hline
\end{tabular}


The density of the frozen wood, $\rho$, in equation (1) can be calculated with the help of the following equations (Deliiski, 2013b):

$$
\begin{gathered}
\rho=\rho_{\mathrm{b}} \cdot \frac{1+u}{1-\frac{S_{\mathrm{v}}}{100} \cdot\left[u_{\mathrm{fsp}}^{293.15}-0.001 \cdot\left(T_{\mathrm{dfr}}-293.15\right)-u\right]} \\
\text { @ } u \leq u_{\mathrm{fsp}} \& T \leq T_{\mathrm{dfr}} \\
\rho=\rho_{\mathrm{b}}(1+u) @ u>u_{\mathrm{fsp}}
\end{gathered}
$$

In equation (19) $S_{\mathrm{v}}$ is the volume shrinkage of the wood (in \%), whose values are given in the last column of Table 1.

\subsection{Computation of a at temperatures $271.15 \mathrm{~K}<$} $T \leq 272.15 \mathrm{~K}$ and wood moisture content $u>$ $u_{\text {fsp }}$

2.2. Izračun koeficijenta toplinske vodljivosti pri temperaturi $271.15 \mathrm{~K}<T \leq 272.15 \mathrm{~K}$ i sadržaju vode $u>u_{\mathrm{fsp}}$

During the calculations of defrosting processes of wood, which contains free water, i.e. when the condition $271.15<T \leq 272.15 \& u>u_{\text {fsp }}$ holds, the wood temperature conductivity must be determined according to the following equation (Deliiski, 2003b):

$$
a\left(T, u, u_{\mathrm{fsp}}\right)=\frac{\lambda\left(T, u, u_{\mathrm{fsp}}\right)}{\left[c\left(T, u, u_{\mathrm{fsp}}\right)+\mathrm{c}_{\mathrm{fw}}\left(T, u, u_{\mathrm{fsp}}\right)\right] \cdot \rho\left(\rho_{\mathrm{b}}, T, u, u_{\mathrm{fsp}}\right)}
$$

where $a$ is temperature conductivity of wood with frozen free water in it $\left(\mathrm{m}^{2} \cdot \mathrm{s}^{-1}\right), \lambda$ is thermal conductivity of the frozen wood $\left(\mathrm{W} \cdot \mathrm{m}^{-1} \cdot \mathrm{K}^{-1}\right), c$ is specific heat capacity of wood with frozen free water in it $\left(\mathrm{J} \cdot \mathrm{kg}^{-1} \cdot \mathrm{K}^{-1}\right), c_{\mathrm{fw}}$ is specific heat capacity of the frozen free water in the wood, $\left(\mathrm{J} \cdot \mathrm{kg}^{-1} \cdot \mathrm{K}^{-1}\right)$. The remaining variables in equation (21) are the same, as in the equation (1).

For the determination of $a$ by equation (21) the values of $\lambda$ and $c$ must be calculated at
$T=\frac{271.15+272.15}{2}=271.65 \mathrm{~K}$ according to above given equations. The value of $\rho$ in equations (1) and (21) must be determined by equations (19) and (20) correspondingly.

For calculation of $c_{\mathrm{fw}}$ in (21) the following equation (Deliiski 2003b, 2004, 2011) has been obtained:

$$
c_{\mathrm{fw}}=3.34 \cdot 10^{5} \cdot \frac{u-u_{\mathrm{fsp}}}{1+u}
$$

\section{RESULTS AND DISCUSSION} 3. REZULTATI I RASPRAVA

For the computation of the wood temperature conductivity according to equations (1) and (21) a software program has been prepared in FORTRAN (Dorn and McCracken 1972), and it has been input in the calculation environment of Visual Fortran Professional developed by Microsoft.

With the help of the program, computations have been made for the determination of $a$ in three cases: at $223.15 \mathrm{~K} \leq T \leq 271.15 \mathrm{~K}$ (i.e. $-60^{\circ} \mathrm{C} \leq t \leq-2{ }^{\circ} \mathrm{C}$ ) $\& 0 \leq u \leq u_{\text {fsp }}$, at $-60{ }^{\circ} \mathrm{C} \leq t \leq-2{ }^{\circ} \mathrm{C} \& u_{\text {fsp }} \leq u \leq 1.2$ $\mathrm{kg} \cdot \mathrm{kg}^{-1}$, and at $271.15 \mathrm{~K}<T \leq 272.15 \mathrm{~K}$ (i.e. $-2{ }^{\circ} \mathrm{C}<$ $\left.t \leq-1{ }^{\circ} \mathrm{C}\right) \& u>u_{\mathrm{fsp}}$. The temperature conductivity cross sectional to the fibers of beech (Fagus Silvatica L.), poplar (Populus alba L.), oak (Quercus petraea Liebl.), walnut (Juglans regia L.), acacia (Robinia pseudoacacia J.) and spruce (Picea abies L.) has been calculated.

\subsection{Wood temperature conductivity cross sectional to} the fibers at $-60^{\circ} \mathrm{C} \leq t \leq-2{ }^{\circ} \mathrm{C} \& 0 \leq u \leq u_{\text {fp }}$

3.1. Toplinska vodljivost drva poprečno na vlakanca pri temperaturi $-60^{\circ} \mathrm{C} \leq t \leq-2^{\circ} \mathrm{C}$ i sadržaju vode $0 \leq u \leq$ $u_{\text {fsp }}$

Fig. 1 and Fig. 2 show, according to equation (1), the calculated change in the temperature conductivity

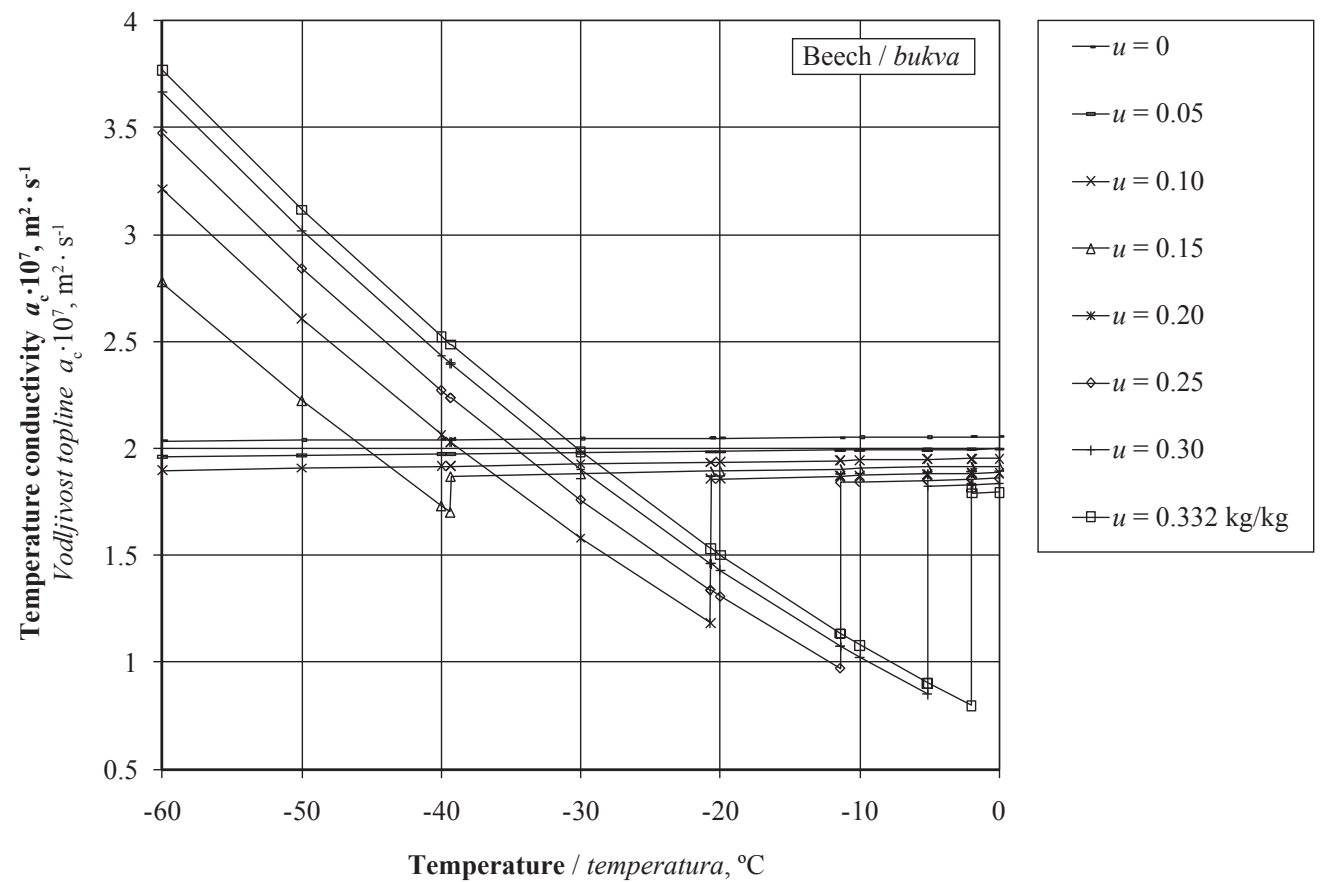

Figure 1 Change in the temperature conductivity of frozen beech wood with $\rho_{\mathrm{b}}=560 \mathrm{~kg} \cdot \mathrm{m}^{-3}$ and $u_{\mathrm{fsp}}^{293.15}=0.31 \mathrm{~kg} \cdot \mathrm{kg}{ }^{-1} \mathrm{cross} \mathrm{sectional}$ to the fibres, depending on $t$ and $u \leq u_{\text {fs }}$

Slika 1. Promjena toplinske vodljivosti smrznute bukovine gustoće $\rho_{\mathrm{b}}=560 \mathrm{~kg} \cdot \mathrm{m}^{-3} \mathrm{i}$ točke zasićenosti vlakanaca $u_{\mathrm{fsp}}^{293.15}=0,31 \mathrm{~kg} \cdot \mathrm{kg}{ }^{-1}$ poprečno na vlakanca u ovisnosti o temperaturi $t$ i pri $u \leq u_{\text {fsp }}$ 


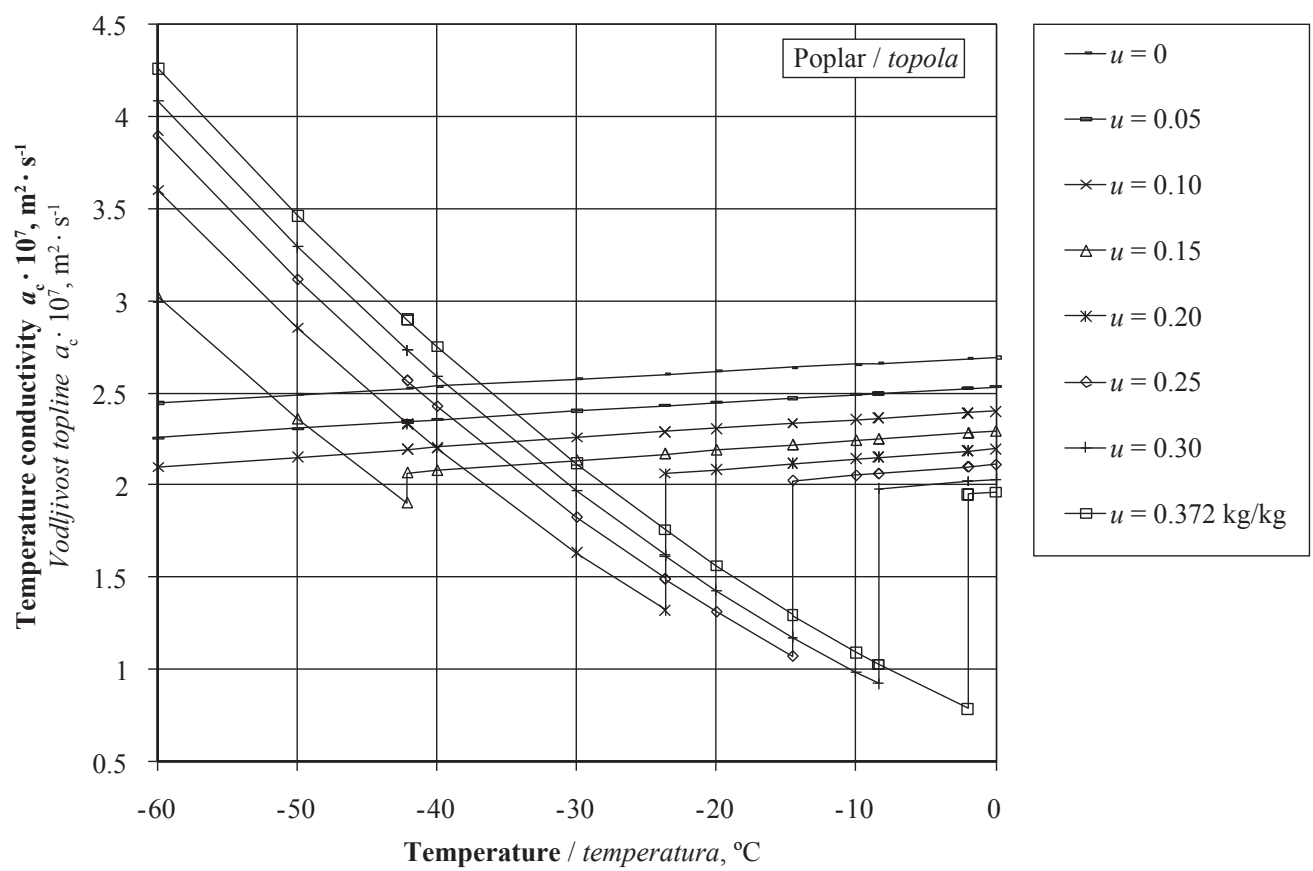

Figure 2 Change in the temperature conductivity of frozen poplar wood with $\rho_{\mathrm{b}}=355 \mathrm{~kg} \cdot \mathrm{m}^{-3}$ and $u_{\mathrm{fsp}}^{293.15}=0.35 \mathrm{~kg} \cdot \mathrm{kg}^{-1} \mathrm{cross}$ sectional to the fibres, depending on $t$ and $u \leq u_{\mathrm{fsp}}$

Slika 2. Promjena toplinske vodljivosti smrznute topolovine gustoće $\rho_{\mathrm{b}}=355 \mathrm{~kg} \cdot \mathrm{m}^{-3} \mathrm{i}$ točke zasićenosti vlakanaca $u_{\mathrm{fsp}}^{293.15}=0,35$ $\mathrm{kg} \cdot \mathrm{kg}^{-1}$ poprečno na vlakanca u ovisnosti o temperaturi $t$ i pri $u \leq u_{\mathrm{fsp}}$

cross sectional to the fibers, $a_{\mathrm{c}}$, of frozen beech and poplar wood, respectively, in the hygroscopic range, depending on $t$ and $u$. During the computations, the values from Table 1 of $\rho_{\mathrm{b}}, u_{\mathrm{fsp}}^{293.15}$, and $S_{\mathrm{v}}$ have been used. The values of $a_{\mathrm{c}}$ for wood not containing ice, i.e. for $u=0$ $\mathrm{kg} \cdot \mathrm{kg}^{-1}, u=0.05 \mathrm{~kg} \cdot \mathrm{kg}^{-1}$ and $u=0.10 \mathrm{~kg} \cdot \mathrm{kg}^{-1}$, as well as for $t>t_{\mathrm{dfr}}=T_{\mathrm{dfr}}-273.15$ at $u \geq 0.15 \mathrm{~kg} \cdot \mathrm{kg}^{-1}$ are calculated according to the equations for non-frozen wood, which are given in (Deliiski, 2003b, 2011; Dzurenda and Deliiski, 2010).

The obtained values of $t_{\text {dfr }}$ according to equations (13) and (14) depending on $u$ for the studied wood species during the calculation of $a_{\mathrm{c}}$ are given in Table 2 . The value of $u_{\text {fsp }}$ obtained according to equation (15) at $T_{\mathrm{dfr}}=271.15 \mathrm{~K}$ (Chudinov, 1966), when the maximum possible amount of frozen bound water in the wood completely melts, for beech wood with $u_{\mathrm{fsp}}^{293.15}=0.31$ $\mathrm{kg} \cdot \mathrm{kg}^{-1}$ is equal to $u_{\mathrm{fsp}}=0.332 \mathrm{~kg} \cdot \mathrm{kg}^{-1}$ and for poplar wood with $u_{\mathrm{fsp}}^{293.15}=0.35 \mathrm{~kg} \cdot \mathrm{kg}^{-1}$ is equal to $u_{\mathrm{fsp}}=0.372$ $\mathrm{kg} \cdot \mathrm{kg}^{-1}$. This values of $u_{\mathrm{fsp}}$ are used as maximum values of $u=u_{\mathrm{fsp}}$ during the computation of $a_{\mathrm{c}}$.

The graphs in Fig. 1 and Fig. 2 show that an increase in $t$ at a given value for $u$ leads to a decrease in $a$ for wood containing ice as a consequence of the increase in $c_{\mathrm{bw}}$ (refer to equation (18)) and to an in- crease in $a$ for wood, which does not contain ice. Also, the slope for the change in $a$ of wood, which contains frozen bound water depending on $t$ is much larger than the slope for the change in $a$ of wood without ice. The change in $a$ depending on $t$ with sufficient precision for practical calculations can be taken as being linear.

From the analysis of Fig. 1 and Fig. 2, it can also be seen that at a given value of $t$, an increase in $u$ for wood containing ice, formed in it from freezing of hygroscopically bound water, causes an increase in $a$. At temperatures, equal to $t_{\mathrm{dfr}}$ (see Table 2), a jump takes place in $a$. This jump in $a$ is explained by the completing of the phase transition of the frozen bound water in the wood at these values for $t$ and $u$, when the influence on $\lambda$ and $c$ of a significant difference in the specific heat capacity of the bound water in a liquid and hard aggregate condition is observed.

The presence of such a jump in $a$ demonstrates the correct reflection in equation (1), and in the mathematical description of $\lambda$ (Deliiski, 2013c) and $c$ of the setting in the theory of wood thermal treatment (Chudinov, 1968), according to which exactly at temperature $t_{\mathrm{dfr}}$ for given value of $u$ the melting of the frozen bound water in the wood is completed.

Table 2 Change in $t_{\mathrm{dfr}}$ (in ${ }^{\circ} \mathrm{C}$ ) of frozen wood depending on wood moisture content and wood species Tablica 2. Promjena temperature $t_{\mathrm{dfr}}\left(\mathrm{u}^{\circ} \mathrm{C}\right)$ smrznutog drva u ovisnosti o sadržaju vode i vrsti drva

\begin{tabular}{|l|c|c|c|c|c|c|}
\hline \multirow{2}{*}{ Wood species } & \multicolumn{5}{|c|}{ Wood moisture content $\boldsymbol{u}, \mathrm{kg}^{\prime} \mathrm{kg}^{-1}$ / Sadržaj vode $u$ drvu, ${\mathrm{kg} \cdot \mathrm{kg}^{-1}}^{-1}$} \\
\cline { 2 - 7 } & 0.15 & 0.20 & 0.25 & 0.30 & 0.332 & 0.372 \\
\hline Beech / bukva & -39.25 & -20.68 & -11.39 & -5.15 & -2.00 & -2.00 \\
\hline Poplar / topola & -42.14 & -23.69 & -14.53 & -8.37 & -5.28 & -2.00 \\
\hline
\end{tabular}


3.2. Wood temperature conductivity cross sectional to the fibers at $-60^{\circ} \mathrm{C} \leq t \leq-2{ }^{\circ} \mathrm{C} \&$ $u_{\mathrm{fsp}} \leq u \leq 1.2 \mathrm{~kg} \cdot \mathrm{kg}^{-1}$

3.2. Toplinska vodljivost drva poprečno na vlakanca pri temperaturi $-60{ }^{\circ} \mathrm{C} \leq t \leq-2{ }^{\circ} \mathrm{C}$ i sadržaju vode $u_{\mathrm{fsp}} \leq u \leq 1,2 \mathrm{~kg} \cdot \mathrm{kg}^{-1}$

Fig. 3 shows, according to equation (1), the calculated change in the temperature conductivity cross sectional to the fibers, $a_{c}$, of frozen beech and poplar wood above the hygroscopic range, depending on $t$ and $u$. During the computations, the values from Table 1 of $\rho_{\mathrm{b}}$ and $u_{\mathrm{fsp}}^{293.15}$ for beech and poplar wood have been used. The values of $a_{\mathrm{c}}$ for wood not containing ice, i.e. for $t>t_{\mathrm{dfr}}=-2{ }^{\circ} \mathrm{C}$ (see equation (14)) at all studied values of $u$ have been calculated according to the equations for non-frozen wood, which are given in (Deliiski, 2003b, 2011; Dzurenda and Deliiski, 2010).

The graphs in Fig. 3 show that an increase in $t$ at a given value for $u$ and an increase in $u$ at a given value for $t$ leads to the change in $a$ both for wood not containing and containing ice from the free water, which is the same as the one shown above for wood, containing only frozen bound water.

The graphs in Fig. 3 also show that at $t=t_{\mathrm{dfr}}=-2$ ${ }^{\circ} \mathrm{C}$ jumps take place in $a$ for the wood with $u>u_{\mathrm{fsp}}$. These jumps are explained by the phase transition into water of the whole amount of the ice, formed by the free water in the wood during defrosting above the hygroscopic range. Namely, at the value of $t=t_{\mathrm{dfr}}=-2{ }^{\circ} \mathrm{C}$, the influence on $a$ of a significant difference in the temperature conductivity of the free water in a liquid and hard aggregate state occurs.

\subsection{Wood temperature conductivity cross} sectional to the fibers at $-2{ }^{\circ} \mathrm{C}<t \leq-1{ }^{\circ} \mathrm{C} \&$ $u>u_{\text {fs }}$

3.3. Toplinska vodljivost drva poprečno na vlakanca pri temperaturi $-2{ }^{\circ} \mathrm{C} \leq t \leq-1{ }^{\circ} \mathrm{C}$ i sadržaju vode $u>u_{\text {fsp }}$

Fig. 4 and Fig. 5 show, according to equation (21), the calculated change in the temperature conductivity of frozen wood from above mentioned six wood species, containing frozen free water, depending on $u>$ $u_{\text {fsp }}$ in the temperature range $-2{ }^{\circ} \mathrm{C}<t \leq-1{ }^{\circ} \mathrm{C}$. During the computations, the values of $\rho_{\mathrm{b}}$ and $u_{\mathrm{fsp}}^{293.15}$ from Table 1 have been used.

The values of $a$ are determined for the entire possible range for the change in the free water in the wood, i.e. for $u_{\text {fsp }}<u \leq u_{\text {max }}$, where the maximum possible moisture content $u_{\max }$ depends on the density $\rho$ of the respective wood specie. The results are shown separately in Fig. 2 and Fig. 3 for the moisture ranges $u_{\mathrm{fsp}}<$ $u \leq 0.4 \mathrm{~kg} \cdot \mathrm{kg}^{-1}$ and $0.4 \mathrm{~kg} \cdot \mathrm{kg}^{-1}<u \leq u_{\max }$, due to the very big differences in the values of $a$ in both ranges.

The results from the calculations show that for values of $u$, which are very close to $u_{\text {fsp }}$, but are slightly larger than $u_{\mathrm{fsp}}$, the values of $a$ in the temperature range $-2{ }^{\circ} \mathrm{C}<t \leq-1{ }^{\circ} \mathrm{C}$ are comparable with those that $a$ has right after the melting of the frozen bound water in the wood. This fact fully corresponds to the physics of the wood defrosting process.

However, as $u$ increases in relation to $u_{\text {fsp }}$, the values of $a$ decrease significantly along a hyperbolic line: from 3.2 to 3.9 times at $u=1.1 u_{\mathrm{fsp}}$, from 17 to 23 times at $u=2 u_{\text {fsp }}$, from 32 to 36 times at $u=3 u_{\text {fsp }}$, up to about 40 times at $u=5 u_{\text {fsp }}$ (when the density of the wood species allows to have such a high moisture content). A reason for this is the strong increasing quantity of the frozen free water in the wood with an increase of $u>$ $u_{\text {fsp }}$ and the related increase in the specific heat capacity $c_{\mathrm{fw}}$, which is a part of the denominator in equation (21).

The drastic decrease of the wood temperature conductivity in the range $-2{ }^{\circ} \mathrm{C}<t \leq-1{ }^{\circ} \mathrm{C}$ for all anatomic directions of wood, which contains frozen free water, causes a significant slowing down of the change in temperature in the frozen wood materials subjected to thermal treatment in this range up to the moment when this frozen water melts completely. This fact is illustrated by many graphs in the specialized literature (Deliiski, 2003b, 2004, 2009, 2013a; Dzurenda and Deliiski, 2010; Steinhagen, 1986, 1991; Khatabbi and Shteinhagen, 1992, 1993, 1995). It confirms the correct reflection in equation (21) of the physical laws that influence $a$ in the shown temperature range.
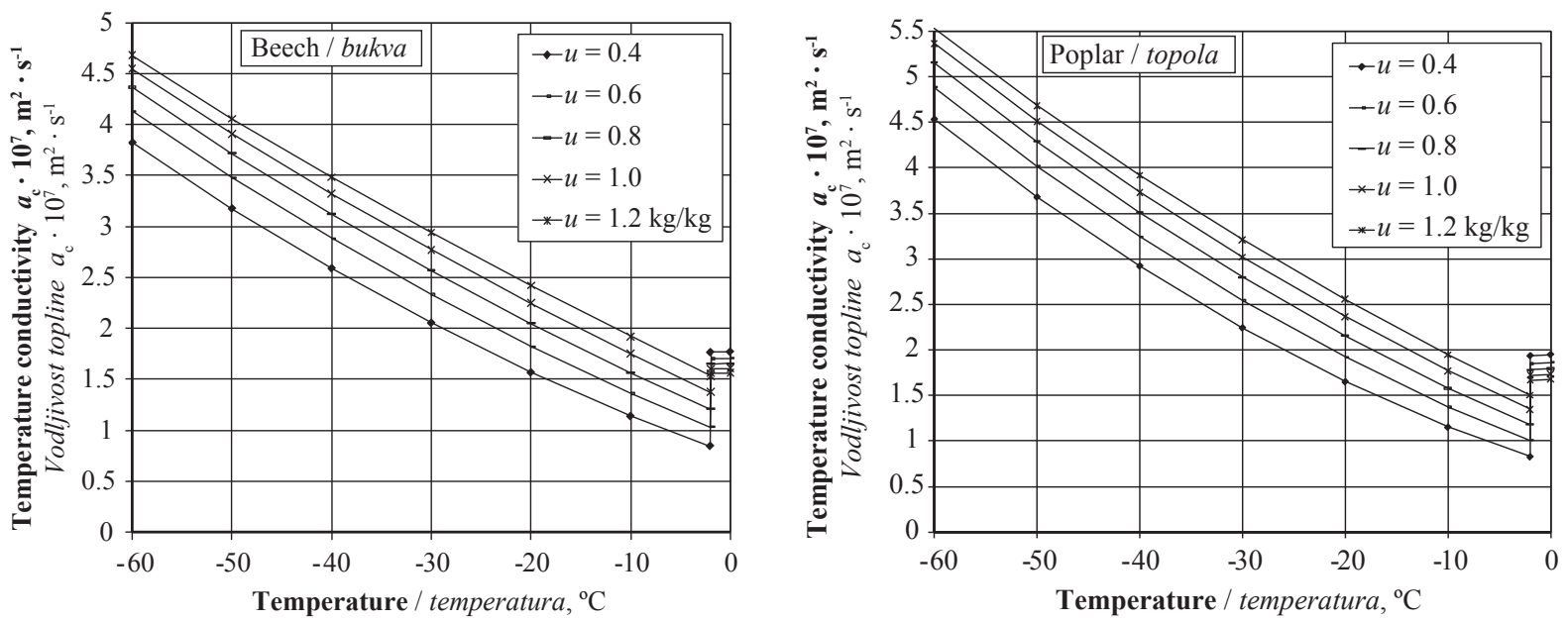

Figure 3 Change in the temperature conductivity of frozen beech (left) and poplar (right) wood cross sectional to the fibres, depending on $t$ and $u>u_{\mathrm{fsp}}$

Slika 3. Promjena toplinske vodljivosti smrznute bukovine (lijevo) i topolovine (desno) poprečno na vlakanca, u ovisnosti o temperaturi $t$ i pri $u>u_{\text {fsp }}$ 


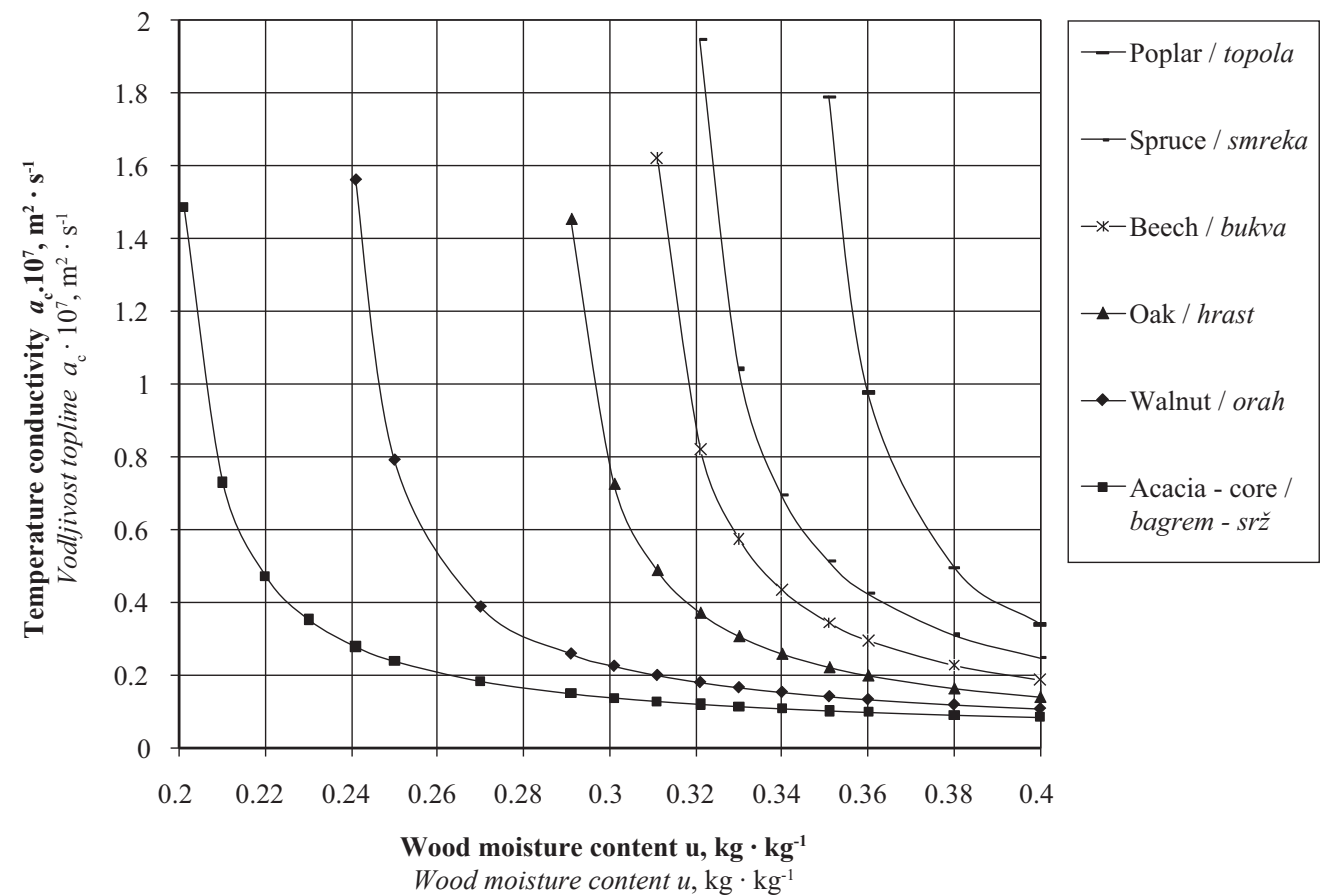

Figure 4 Change in the wood temperature conductivity of poplar, spruce, beech, oak, walnut and acacia cross sectional to the fiber depending on $u_{\mathrm{fsp}}<u \leq 0.4 \mathrm{~kg} \cdot \mathrm{kg}^{-1}$ in the range $-2{ }^{\circ} \mathrm{C} \leq t<-1^{\circ} \mathrm{C}$

Slika 4. Promjena toplinske vodljivosti topolovine, smrekovine, bukovine, hrastovine, orahovine i bagremovine poprečno na vlakanca, u ovisnosti sadržaju vode $u_{\text {fsp }}<u \leq 0.4 \mathrm{~kg} \cdot \mathrm{kg}^{-1}$ i pri temperaturi $-2{ }^{\circ} \mathrm{C} \leq t<-1{ }^{\circ} \mathrm{C}$

3.4 Computation of the 2D temperature distribution in frozen logs during their defrosting

3.4. Proračun 2D raspodjele temperature $u$ smrznutom trupcu tijekom odmrzavanja

The above results have been used for the calculation of log defrosting according to the following mathematical model (Deliiski, 2003b):

$$
\begin{aligned}
\frac{\partial T}{\partial \tau}= & a_{\mathrm{r}}\left(T, u, u_{\mathrm{fsp}}, \rho_{\mathrm{b}}, S_{\mathrm{v}}\right) \cdot\left(\frac{\partial^{2} T}{\partial r^{2}}+\frac{1}{\mathrm{r}} \cdot \frac{\partial T}{\partial r}\right) \\
& +a_{\mathrm{p}}\left(T, u, u_{\mathrm{fsp}}, \rho_{\mathrm{b}}, S_{\mathrm{v}}\right) \cdot \frac{\partial^{2} T}{\partial z^{2}}
\end{aligned}
$$

with an initial condition

$$
T(r, z, 0)=T_{0}
$$

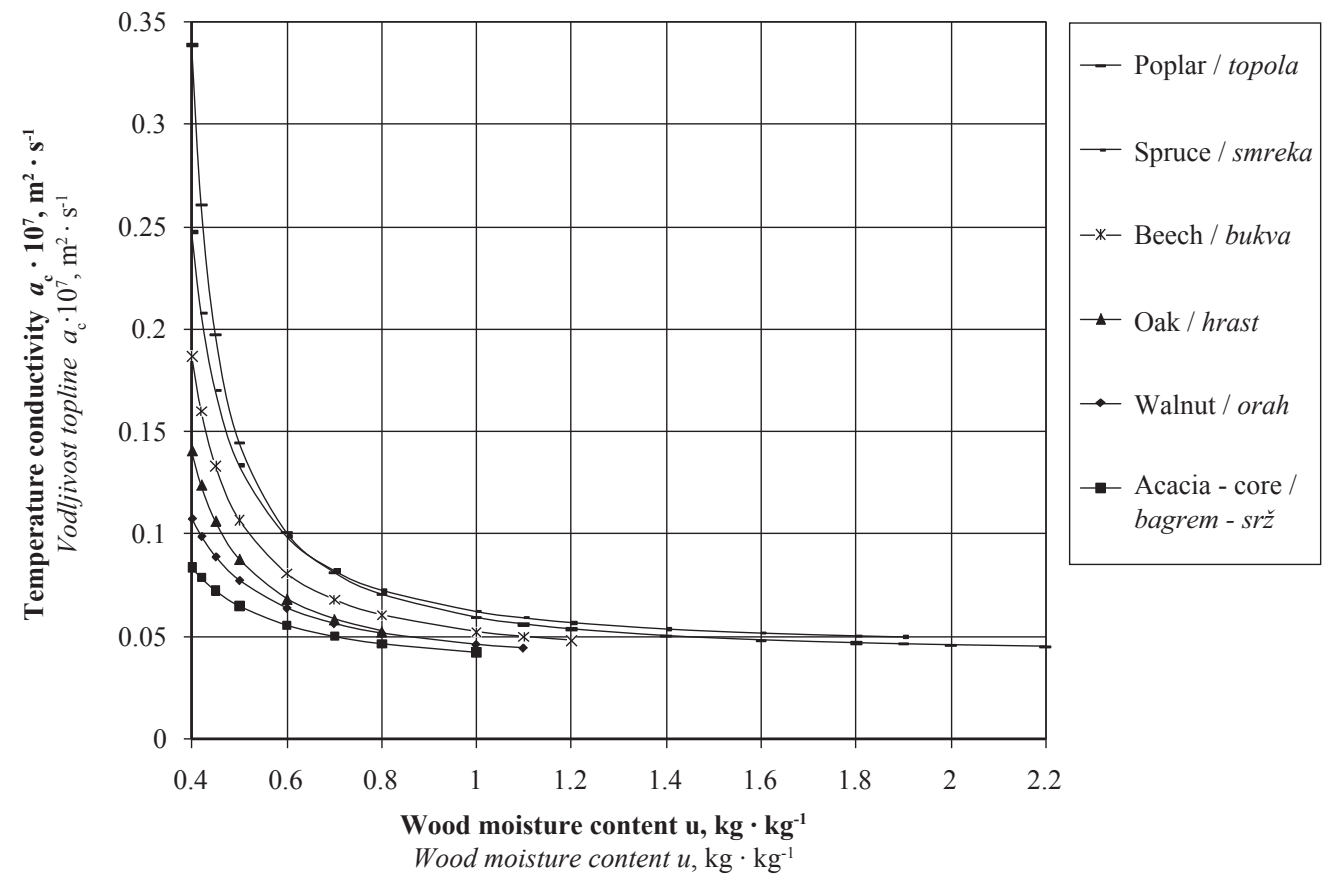

Figure 5 Change in the wood temperature conductivity of poplar, spruce, beech, oak, walnut and acacia cross sectional to the fiber depending on $0.4 \mathrm{~kg} \cdot \mathrm{kg}^{-1}<u \leq u_{\max }$ in the range $-2{ }^{\circ} \mathrm{C} \leq t<-1{ }^{\circ} \mathrm{C}$

Slika 5. Promjena toplinske vodljivosti topolovine, smrekovine, bukovine, hrastovine, orahovine i bagremovine poprečno na vlakanca, u ovisnosti o sadržaju vode $0.4 \mathrm{~kg} \cdot \mathrm{kg}^{-1}<u \leq u_{\text {max }}$ i pri temperaturi $-2{ }^{\circ} \mathrm{C} \leq t<-1{ }^{\circ} \mathrm{C}$ 

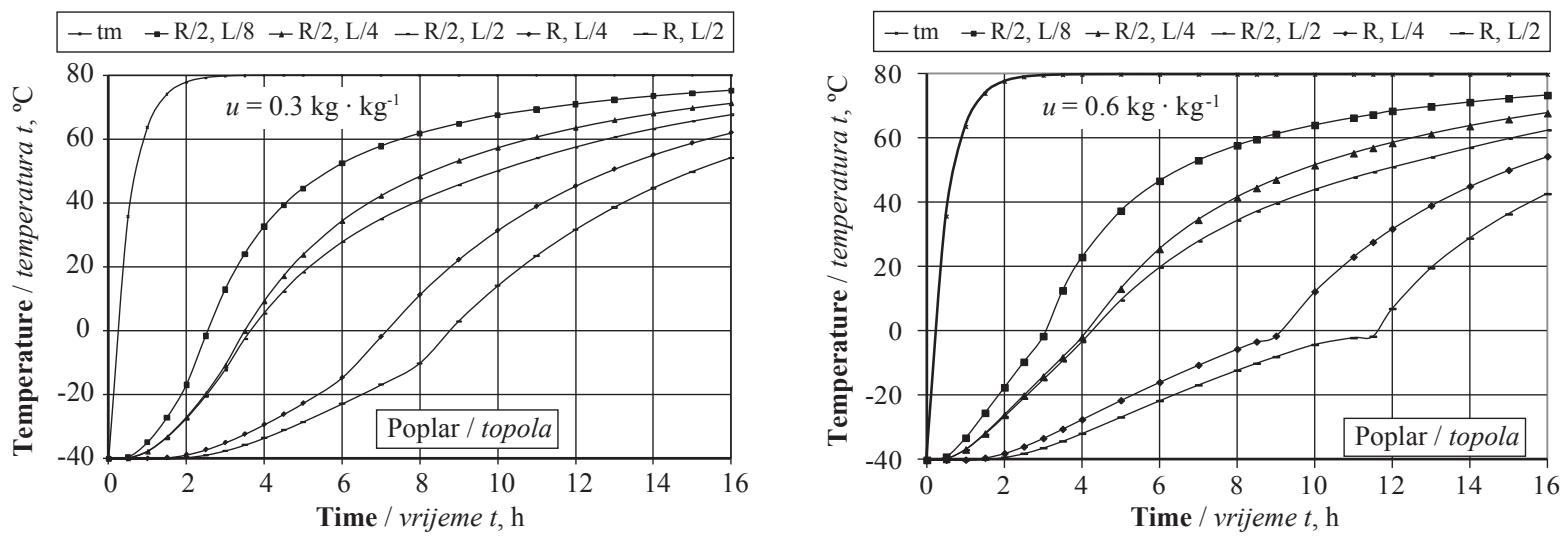

Figure 6 Change in $t$ in the longitudinal section of poplar logs with $R=0.2 \mathrm{~m}, L=0.8 \mathrm{~m}, t_{0}=-40^{\circ} \mathrm{C}, u=0.3 \mathrm{~kg} \cdot \mathrm{kg}^{-1}(\mathrm{left})$ and $u=0.6 \mathrm{~kg} \cdot \mathrm{kg}^{-1}$ (right) during their defrosting at $t_{\mathrm{m}}=80^{\circ} \mathrm{C}$

Slika 6. Promjena temperature u longitudinalnom presjeku topolova trupca promjera $R=0,2 \mathrm{~m}$, duljine $L=0,8 \mathrm{~m}$, temperature $t_{0}=-40^{\circ} \mathrm{C}$, sadržaja vode $u=0,3 \mathrm{~kg} \cdot \mathrm{kg}^{-1}$ (lijevo) i sadržaja vode $u=0,6 \mathrm{~kg} \cdot \mathrm{kg}^{-1}$ (desno) tijekom procesa odmrzavanja pri temperaturi $t_{\mathrm{m}}=80^{\circ} \mathrm{C}$

and a boundary condition for thermal treatment of the logs in agitated hot water at their prescribed surface temperature:

$$
T(0, z, \tau)=T(0, z, \tau)=T_{\mathrm{m}}(\tau)
$$

where $a_{\mathrm{r}}$ and $a_{\mathrm{p}}$ are temperature conductivities of the wood in radial direction and parallel to the fiber, respectively $\left(\mathrm{m}^{2} \cdot \mathrm{s}^{-1}\right), r$ is radial coordinate: $0 \leq r \leq R, R$ is radius of the $\log (\mathrm{m}), z$ is longitudinal coordinate: 0 $\leq z \leq L / 2, L$ is length of the $\log (\mathrm{m}), T$ is temperature $(\mathrm{K}), T_{0}$ is initial temperature of the log subjected to defrosting (K), $T_{\mathrm{m}}$ is temperature of the processing (heating) medium $(\mathrm{K}), u$ is wood moisture content $\left(\mathrm{kg} \cdot \mathrm{kg}^{-1}\right)$, $u_{\text {fsp }}$ is wood moisture content at fibre saturation point $\left(\mathrm{kg} \cdot \mathrm{kg}^{-1}\right), \rho_{\mathrm{b}}$ is basic density of the wood $\left(\mathrm{kg} \cdot \mathrm{m}^{-3}\right), S_{\mathrm{v}}$ is volume shrinkage of the wood (\%), $\tau$ is time (s).

For the numerical solution of the mathematical model, which is presented in common form by equations (23), (24), and (25), a software package has been prepared in the calculation environment of Visual Fortran Professional. With the help of the software package, computations have been made for the determination of the $2 \mathrm{D}$ non-stationary change in the temperature in frozen poplar logs subjected to defrosting with $R=$ $0.2 \mathrm{~m}, L=0.8 \mathrm{~m}, t_{0}=-40{ }^{\circ} \mathrm{C}$ and two values of wood moisture content $u=0.3 \mathrm{~kg} \cdot \mathrm{kg}^{-1}$ and $u=0.6 \mathrm{~kg} \cdot \mathrm{kg}^{-1}$ during their 16 hours of heating in agitated hot water with $t_{\mathrm{m}}=80^{\circ} \mathrm{C}$. The $\log$ with $u=0.3 \mathrm{~kg} \cdot \mathrm{kg}^{-1}$ contains almost the maximum possible amount of frozen bound water in the wood and does not contain frozen free water. The $\log$ with $u=0.6 \mathrm{~kg} \cdot \mathrm{kg}^{-1}$ contains not only frozen bound water but also contains a significant amount of frozen free water.

The increasing of the heating medium temperature, $t_{\mathrm{m}}$, from the value of $t_{\mathrm{m} 0}=t_{0}$ to $t_{\mathrm{m}}=80^{\circ} \mathrm{C}=\mathrm{const}$ grows exponentially with time constant, equal to 1800 $\mathrm{s}$. This increasing of $t_{\mathrm{m}}$ at the beginning of log heating can be seen in the Fig. 6 . The values of $R, L, t_{\mathrm{m}}$, and $u$ have been selected so as to correspond to cases common in practice. The duration of $16 \mathrm{~h}$ of $\log$ heating at $t_{\mathrm{m}}=80^{\circ} \mathrm{C}$ has been proven as sufficient for complete melting of the ice in the studied logs.

During the computations, the values from Table 1 of $\rho_{\mathrm{b}}, u_{\mathrm{fsp}}^{293.15}$, and $S_{\mathrm{v}}$ for poplar wood have been used. The calculations have been done with values of $a_{\mathrm{r}}=$ $1.04 a_{\mathrm{c}}$ and $a_{\mathrm{p}}=1.95 a_{\mathrm{r}}$ (Deliiski, 2003b), where $a_{\mathrm{c}}$ is the temperature conductivity of the poplar wood cross sectional to the fibers, whose values for $u=0.3 \mathrm{~kg} \cdot \mathrm{kg}^{-1}$ and $u=0.6 \mathrm{~kg} \cdot \mathrm{kg}^{-1}$ can be seen in Fig. 2, Fig. 3 (right), and Fig. 5.

Fig. 6 shows the computed change in the surface temperature of the logs, which is equal to $t_{\mathrm{m}}$, and also in the temperature in 5 characteristic points in the $1 / 4$ of the longitudinal section of logs (because of its symmetry to the remaining $3 / 4$ of the section). The coordinates of the characteristic points are given in the legend of the graphs.

The curves of the log axe situated on characteristic points with coordinates $(\mathrm{R}, \mathrm{L} / 4)$ and $(\mathrm{R}, \mathrm{L} / 2)$ on the right part of Fig. 6 show the specific almost horizontal sections of retention of the temperature for a long period of time in the range from $-2{ }^{\circ} \mathrm{C}$ to $-1{ }^{\circ} \mathrm{C}$, while in these points a complete melting of the frozen free water in the wood occurs. Such retention of the temperature in the range from $-2{ }^{\circ} \mathrm{C}$ to $-1{ }^{\circ} \mathrm{C}$ has been observed in wide experimental studies during the defrosting process of pine logs with frozen free water in them (Steinhagen, 1986; Khattabi and Steinhagen, 1992, 1993).

The reason for the temperature retention in the range from $-2{ }^{\circ} \mathrm{C}$ to $-1{ }^{\circ} \mathrm{C}$ is the very low value of the temperature conductivity coefficient $a_{\mathrm{c}}$, which is equal to $0.1 \cdot 10^{-7} \mathrm{~m}^{2} \cdot \mathrm{s}^{-1}$ for the poplar wood with $u=0.6$ $\mathrm{kg} \cdot \mathrm{kg}^{-1}$ in this range (see Fig. 5). In the range $-40{ }^{\circ} \mathrm{C} \leq$ $t \leq-2{ }^{\circ} \mathrm{C}$, the value of $a_{\mathrm{c}}$ of the same frozen poplar wood changes from $a_{\mathrm{c}}=3.24 \cdot 10^{-7} \mathrm{~m}^{2} \cdot \mathrm{s}^{-1}$ to $a_{\mathrm{c}}=1.01 \cdot 10^{-}$ ${ }^{7} \mathrm{~m}^{2} \cdot \mathrm{s}^{-1}$ (see Fig. 3-right), i.e. it is from 32.4 to 10.1 times larger comparing with $a_{\mathrm{c}}=0.1 \cdot 10^{-7} \mathrm{~m}^{2} \cdot \mathrm{s}^{-1}$. Because of this, the temperature in the logs with frozen free water in them increases much faster in the range $-40{ }^{\circ} \mathrm{C} \leq t \leq-2{ }^{\circ} \mathrm{C}$ than in the range $-2{ }^{\circ} \mathrm{C}<t \leq-1{ }^{\circ} \mathrm{C}$. 
Analogically, the almost horizontal sections in the change of the wood temperature are absent during defrosting of the ice, formed only by bound water in the wood (see the left part of Fig. 6).

\section{CONCLUSIONS \\ 4. ZAKLJUČAK}

The present paper describes the approach suggested by the authors for the computation of the temperature conductivity of frozen wood materials at temperatures below $-1{ }^{\circ} \mathrm{C}$ during their defrosting. The approach takes into account to a maximum degree the physics of the processes of melting of the ice, formed by both the bound and the free water in the wood. It reflects the influence of the temperature, moisture content and density of the wood, and for the first time also the influence of the fiber saturation point of each wood species on its temperature conductivity in a frozen state.

The obtained results for poplar, spruce, beech, oak, walnut, and acacia show that, when all other conditions are equal, the wood temperature conductivity during melting of the frozen bound water is up to some tens of times larger than the wood temperature conductivity during melting of the frozen free water in the wood. This fact determined for the first time quantitatively for the studied wood species causes a significant slowing down of the change in temperature in the frozen wood materials subjected to thermal treatment up to the moment, when the frozen free water melts completely.

It has been determined that the change in $a$ depending on $t$ with sufficient precision of calculations can be taken as linear for practical reasons, when $t<-2$ ${ }^{\circ} \mathrm{C}$ for all $0 \leq u \leq u_{\mathrm{fsp}}$ and hyperbolic when $-2{ }^{\circ} \mathrm{C}<t$ $\leq-1{ }^{\circ} \mathrm{C}$ and simultaneously with this $u>u_{\mathrm{fsp}}$.

The results of this work can be used for both technological and other engineering calculations and analysis of processes of thermal and hydrothermal treatment of wood materials, as well as in system software for model based automatic control (Hadjiski, 2003, 2013) of such treatment. The suggested methodology for the computation of the temperature conductivity of frozen wood during its defrosting can also be used for science based dimensioning of the mentioned processes with the help of all classical approaches, which are well known from the textbooks and other specialized literature.

\section{Acknowledgement - Zahvala}

This document was supported by the grant No BG051PO001-3.3.06-0056, financed by the Human Resources Development Operational Programme (2007 2013) and co-financed jointly by the ESF of the EU and the Bulgarian Ministry of Education and Science.

\section{REFERENCES}

\section{LITERATURA}

1. Chudinov, B. S., 1966: Theoretical Research of Thermo Physical Properties and Thermal Treatment of Wood. DSc Dissertation, Krasnoyarsk, SibLTI (in Rusian).
2. Chudinov, B. S., 1968: Theory of Thermal Treatment of Wood. Publisher "Nauka", Moscow (in Russian).

3. Deliiski, N., 1977: Computation of the Non-stationary Temperature Distribution in the Wood during its Heating by Heat Conductivity. Part I: Mathematical Model of the Wood Heating Process by Heat Conductivity. Holz RohWerkstoff, 35 (4): 141-145. (in German). http://dx.doi.org/10.1007/BF02625331

4. Deliiski, N., 1990: Mathematical Description of the Specific Heat Capacity of Non-frozen and Frozen Wood. Proceedings of the VIII ${ }^{\text {th }}$ International Symposium on Fundamental Research of Wood. Warscow, 229-233 (in German).

5. Deliiski, N., 1994: Mathematical Description of the Thermal Conductivity Coefficient of Non-frozen and Frozen Wood. Proceedings of the $2^{\text {nd }}$ International Symposium on Wood Structure and Properties '94, TU-Zvolen, 127-134.

6. Deliiski, N., 2003a: Microprocessor System for Automatic Control of Logs' Steaming Process. Drvna industrija, 54 (4): 191-198.

7. Deliiski, N., 2003b: Modeling and Technologies for Steaming of Wood Materials in Autoclaves. DSc. Dissertation, University of Forestry, Sofia, 2003 (in Bulgarian).

8. Deliiski, N., 2004: Modelling and Automatic Control of Heat Energy Consumption Required for Thermal Treatment of Logs. Drvna industrija, 55 (4): 181-199.

9. Deliiski, N., 2009: Computation of the 2-Dimensional Transient Temperature Distribution and Heat Energy Consumption of Frozen and Non-frozen Logs. Wood Research, 54 (3): 67-78.

10. Deliiski, N., 2011: Transient Heat Conduction in Capillary Porous Bodies, p. 149-176. In: Convection and Conduction Heat Transfer. InTech Publishing House, Rijeka. http://dx.doi.org/10.5772/21424

11. Deliiski, N., 2013a: 3D Modeling and Visualization of the Non-stationary Temperature Distribution during Heating of Frozen Wood. Drvna industrija, 64 (4): 293-303.

12. Deliiski, N., 2013b: An Engineering Approach for the Calculation of the Wood Density in the Hygroscopic Diapason during Wood Defrosting. 10 $0^{\text {th }}$ International Symposium "Selected Processes at the Wood Processing". September 11-13, Ružomberok, Slovakia, Volume of articles, $9 \mathrm{c}$.

13. Deliiski, N., 2013c: Computation of the Wood Thermal Conductivity during Defrosting of the Wood. Wood research, 58 (4): 637-650.

14. Deliiski, N.; Dzurenda, L., 2010: Modeling of the Thermal Processes in the Technologies for Wood Thermal Treatment. TU Zvolen, Slovakia (in Russian).

15. Hadjiski, M., 2003: Mathematical Models in Advanced Technological Control Systems. Automatic \& Informatics, 37 (3): 7-12. (in Bulgarian).

16. Hadjiski, M., 2013: Functionality and Structure Development Advanced Industrial Control System. Automatic \& Informatics, 47 (4): 7-14. (in Bulgarian).

17. Dorn, W. S.; McCracken, D. D., 1972: Numerical Methods with FORTRAN IV: Case Studies. New York, John Willey \& Sons, Inc.

18. Dzurenda, L.; Deliiski, N., 2010: Thermal Processes in the Technologies for Wood Processing. Zvolen, Technical University in Zvolen (in Slovak).

19. Kanter, K. R., 1955: Investigation of the Thermal Properties of Wood. PhD Thesis, Moscow, MLTI (in Russian).

20. Khattabi, A.; Steinhagen, H. P., 1992: Numerical Solution to Two-dimensional Heating of Logs. Holz RohWerkstoff, 50: 308-312.

http://dx.doi.org/10.1007/BF02615359 
21. Khattabi, A.; Steinhagen, H. P., 1993: Analysis of Transient Non-linear Heat Conduction in Wood Using Finitedifference Solutions. Holz Roh- Werkstoff, 51: 272-278. http://dx.doi.org/10.1007/ BF02629373

22. Khattabi, A.; Steinhagen, H. P., 1995: Update of "Numerical Solution to Two-dimensional Heating of Logs". Holz Roh- Werkstoff, 53: 93-94. http://dx.doi.org/10.1007/BF02716399

23. Kurjatko, S. et al., 2010: Quality Parameters of the Wood Influencing its Finale Usage. Zvolen, Technical University in Zvolen (in Slovak).

24. Nikolov, S.; Videlov, C., 1987: Manual for Wood Drying. Zemizdat, Sofia, (in Bulgarian).

25. Perelygin, L. M., 1965: Wood Science. SVTL, Bratislava (in Slovak).

26. Pervan, S., 2009: Technology for Treatment of Wood with Water Steam. University in Zagreb (in Croatian).

27. Požgaj, A.; Chovanec, D.; Kurjatko, S.; Babiak, M., 1997: Structure and Properties of Wood. $2^{\text {nd }}$ edition, Priroda a.s., Bratislava (in Slovak).

28. Reginač, L. et al., 1990: Wood Science II. VSLD in Zvolen (in Slovak).

29. Sergovski, P. S., 1975: Hydrothermal Treatment and Conserving of Wood. Publisher "Lesnaya promyshlennost", Moscow (in Rusian).

30. Shubin, G. S., 1990: Drying and Thermal Treatment of Wood. Publisher "Lesnaya promyshlennost", Moskow (in Russian).
31. Stamm, A. J., 1964: Wood and Cellulose Science. The Ronald Press Company, New York.

32. Steinhagen, H. P., 1986: Computerized Finite-difference Method to Calculate Transient Heat Conduction with Thawing. Wood Fiber Sci., 18 (3): 460-467.

33. Steinhagen, H. P., 1991: Heat Transfer Computation for a Long, Frozen Log Heated in Agitated Water or Steam - A Practical Recipe. Holz Roh- Werkstoff, 49: 287-290. http://dx.doi.org/10.1007/ BF02663790

34. Trebula, P., 1996: Drying and Hydrothermal Treatment of Wood. Technical University in Zvolen (in Slovak).

35. Trebula, P.; Klement, I., 2002: Drying and Hydrothermal Treatment of Wood. Technical University in Zvolen (in Slovak).

36. Videlov, H., 2003: Drying and Thermal Treatment of Wood. Publishing House of the University of Forestry, Sofia (in Bulgarian).

\section{Corresponding address:}

Prof. NENCHO DELIISKI, Ph.D., DSc.

Faculty of Forest Industry

University of Forestry

Kliment Ohridski Blvd. 10

1756 Sofia, BULGARIA

e-mail: deliiski@netbg.com 